IRA-International Journal of Applied Sciences ISSN 2455-4499; Vol.04, Issue 01 (2016)

Institute of Research Advances http://research-advances.org/index.php/IRAJAS

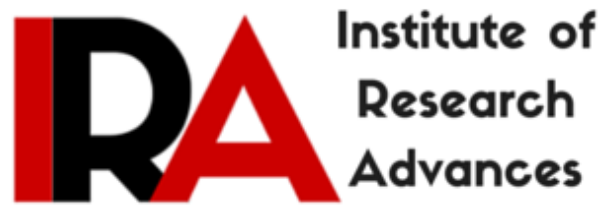

\title{
Single Strand Conformational Polymorphism as a Molecular Marker for Detection of Variation between the Small Length ss DNA of Azospirillum, Phosphobacteria and Pseudomonas from the inoculated Bhendi field (COBH 1)
}

\author{
M. Jeya Bharathi ${ }^{1}$, D. Balachandar ${ }^{2} \&$ K. Kumar ${ }^{3}$ \\ 1,2,3 Department of Agricultural Microbiology, Tamil Nadu Agricultural \\ University, Coimbatore - 641 003, India.
}

DOI: http://dx.doi.org/10.21013/jas.v4.n1.p23

\section{How to cite this paper:}

Bharathi, M., Balachandar, D., \& Kumar, K. (2016). Single Strand Conformational Polymorphism as a Molecular Marker for Detection of Variation between the Small Length ss DNA of Azospirillum, Phosphobacteria and Pseudomonas from the inoculated Bhendi field (COBH 1). IRA-International Journal of Applied Sciences (ISSN 24554499), 4(1). doi:http://dx.doi.org/10.21013/jas.v4.n1.p23

(C) Institute of Research Advances

(cc) EY-NC

This works is licensed under a Creative Commons Attribution-Non Commercial 4.0 International License subject to proper citation to the publication source of the work.

Disclaimer: The scholarly papers as reviewed and published by the Institute of Research Advances (IRA) are the views and opinions of their respective authors and are not the views or opinions of the IRA. The IRA disclaims of any harm or loss caused due to the published content to any party. 


\begin{abstract}
Single strand conformational polymorphism is used to identify specific microorganism from the microbial ecosystem at field level. Here the double strand DNA of each organism is converted to single strand and allowed to run in polyacrylamide gel. SSCP can differentiate small variation within same length DNA of different organism due to the difference in retention time, temperature, ionic strength and electrophorotic mobility of ss DNA. This concept is used in this experiment to identify the inoculated microbial consortium from the field by comparison with microbial consortium and pure culture. Azospirillum (Azospirillum brasilense sp 7) and phosphobacteria (Bacillus megaterium var. phosphaticum) and Pseudomonas fluorescens (Pf 1) cultures were used for development of liquid microbial consortium for precision farming system. Inoculated microbes from the field were identified through SSCP-PCR analysis. Appearance of unique domain of $V_{1}$ to $V_{9}$ region of 16srRNA is universal for all bacteria and archae microbial community. Universal primers were used to amplify the $V_{1}$ to $V_{2}$ region of 16 srRNA gene of pure culture, microbial consortium and soil sample from inoculated field for SSCP gel electrophoresis. This study revealed that similar banding pattern was observed between soil sample from inoculated field, microbial consortiums and pure cultures. This experiment proved that SSCP gel electrophoresis is a powerful technique to find specific microorganism in the field in comparison with its pure culture strains without characterization of microorganism.
\end{abstract}

Keywords: Microorganism, Inoculated field, SSCP, microbial consortium

\title{
Introduction
}

\section{Single strand conformational polymorphism}

Single-strand conformational polymorphism (SSCP) is defined as conformational difference of single-stranded nucleotide sequences of identical length as induced by differences in the sequences under certain experimental conditions. This property allows sequences to be distinguished by means of polyacrylamide gel electrophoresis, which separates fragments according to their different conformations (Masato Orita, 1989).

A single nucleotide change in a particular sequence, as seen in a double-stranded DNA, cannot be distinguished by electrophoresis, because the physical properties of the double strands are almost identical for both alleles. But in case of single-stranded DNA undergoes a 3-dimensional folding after denaturation and form a unique conformational state based on its DNA sequence. The difference in shape between two single-stranded DNA with different sequences can cause them to migrate differently on polyacrylamide gel, even though the number of nucleotides is same, which is, in fact, an application of SSCP.

\section{SSCP for diversity analysis of bacteria}

Various PCR based molecular typing methods have been developed for the analysis of microbial communities viz., Denaturating Gradient Gel Electrophoresis (DGGE) (Diez et al., 2001), Temperature Gradient Gel Electrophoresis (TGGE) (Felske, 1999, Felske et al., 1996 and Zoetendal et al., 1998) and Temporal Temperature Gel Electrophoresis (TTGE) (Ogier et al., 2002), TerminalRestriction Fragment Length Polymorphism (TRFLP)(Moesender et al., 1999 and Osborn et al.,2000) and Single-Strand Conformation Polymorphism (SSCP). These methods provide a rapid fingerprint of a complex microbial community without cultivation.

Because of the use of universal primers, SSCP can be applied without any priori information on the species and then can give a more objective view of the microbial community. SSCP has been applied to study microbial communities in water (Lee et al., 1996), in the compost of organic 
agricultural substrate and in anaerobic digestors (Leclerc et al., 2001 and Zumstein et al., 2000). This technique has also been used in clinical microbiology to rapidly differentiate bacteria from blood culture (Turenne et al., 2000). These direct molecular techniques have been applied to the studies of food microbiology (Cocolin et al., 2000 and Coppola et al., 2001). Duthoit et al. (2003) used 16srRNA gene come SSCP technique to study the diversity of microflora during production of registered designation of origin (RDO) saler's cheese. SSCP has also been used to distinguish between 16S-23S rRNA interspacer regions of selected bacterial strains (Scheinert et al., 1996) under different environmental condition. Even though lot of work has been done using SSCP in different area, field level identification of microbes is not yet clear. So the current research is focused for SSCP -PCR under field level.

\section{SSCP for detection of particular bacteria in ecosystem}

Methods commonly used in taxonomy can be utilized to differentiate between organisms from microbial communities, but they require cultivation of purified isolates from environmental samples (Mahaffee and Kloepper, 1997 and Mills and Wassel, 1980). Due to the intrinsic selectivity of each selected cultivation technique, growth of specific members is enhanced, decreased, or even inhibited, and thus, species numbers (richness) and abundances (evenness) obtained in the laboratory by cultivation-dependent methods mostly do not reflect the actual in situ diversity (Wagner et al., 1993 and Ward et al., 1990).

In SSCP analysis, single-stranded DNA is formed during a denaturing step immediately before electrophoretic analysis and electrophoretic separation itself is conducted under nondenaturing conditions. In case of standard SSCP, the majority of products with 16S rRNA genes amplified from pure cultures were found to be double-stranded DNA after electrophoresis. In contrast, with our new approach, which implemented the removal of the phosphorylated DNA strand, double-stranded product was reduced to concentrations close to the level of detection.

\section{Materials and methods}

\section{Sources of microbial inoculants}

Azospirillum (Azospirillum brasilense sp 7) and phosphobacteria (Bacillus megaterium var. phosphaticum) cultures used in this study were obtained from the Biofertilizer Production and Quality Control Unit, Department of Agricultural Microbiology, Tamil Nadu Agricultural University, Coimbatore. Pseudomonas (Pseudomonas fluorescens $(P f 1)$ ) culture used in this study was obtained from the Biocontrol Unit, Department of Plant Pathology, Tamil Nadu Agricultural University, and Coimbatore.

\section{Compatibility test of the inoculants}

Azospirillum brasilense sp 7, phosphate solubilizing bacteria (Bacillus megaterium var. phosphaticum) and Pseudomonas fluorescens (Pf1) were tested for compatibility of growth by cross streak assay in nutrient agar medium (Allen, 1953). To test the compatibility of B. megaterium var. phosphaticum with other cultures, B. megaterium var. phosphaticum was streaked as a strip at 1 end of the plate and incubated for $24 \mathrm{hrs}$ to form a thick growth. The test cultures of A. brasilense sp 7 and Pseudomonas fluorescens were streaked perpendicular to B. megaterium culture. The plates were incubated for $48 \mathrm{hrs}$ and observed for the growth of Azospirillum and Pseudomonas strains. Likewise compatibility of $A$. brasilense sp 7 and Pseudomonas fluorescens ( $\mathrm{Pf} 1$ ) with other cultures was also tested.

\section{Standardization of incubation time and growth rate of pure culture for development of microbial consortium}

The Azospirillum culture was grown in sodium malate broth (Okon et al., 1977), phosphobacterial and Pseudomonas cultures were grown in nutrient broth (Rangaswamy and Bagyaraj, 1966) and King's B broth (King et al., 1954,) respectively in 250ml broth for incubation upto 5 days. The broth was centrifuged @ 10,000 rpm for 10 min. in high volume centrifuge. 
The population of Azospirillum, phosphobacteria and Pseudomonas were enumerated by following drop plate method for standardization of incubation time and mixing ratio for development of liquid microbial consortium.

\section{Drop plate method (Somasegaran and Hoben, 1988)}

$\mathrm{N}_{2}$ free malic acid (Okon et al., 1977), Sperber's hydroxy apatite agar (Sperber, 1958) and King's B medium were prepared, and poured in sterile Petri plates separately. The plates were kept at room temperature for $48 \mathrm{hrs}$. The agar surface was divided into 6 quadrants. A quantity of $10 \mu \mathrm{L}$ from each dilution of $10^{-19}, 10^{-20}, 10^{-21}, 10^{-22}, 10^{-23}$ and $10^{-24}$ of the microbial consortium was placed in a quadrant. The population of Azospirillum was enumerated after five days, in case of phosphobacteria and Pseudomonas after 2 days to study the maximum survival capacity of the inoculant present in the microbial consortium.

\section{Development of liquid microbial consortium for precision farming system}

The mixing ratio of inoculum viz., Azospirillum brasilense sp 7, Bacillus megaterium var. phosphaticum and Pseudomonas fluorescens were fixed based on the result of standardization experiment for development of microbial consortium with $10^{12}$ cells $/ \mathrm{mL}$ of each culture. Consortium was prepared within $10 \mathrm{mM}$ of phosphate buffer with $10 \%$ glycerol for cell protection.

\section{Field experiment}

Field experiments were carried out to assess the liquid microbial consortium in Bhendi $(\mathrm{COBH} 1)$ field under precision farming system at Eastern Block, Tamil Nadu Agricultural University, Coimbatore during 10.10.2008 to 30.12.2008. It lies between $11^{\circ} \mathrm{N}$ latitude and $77^{\circ} \mathrm{E}$ longitude, at an altitude of $426 \mathrm{~m}$ above MSL. The experiments were laid out in a randomized block design with eight treatments and three replications.

\section{SSCP as a molecular marker for identification of inoculants from the field}

SSCP gel electrophoresis was carried out to find the inoculated microbes from the field. The genomic DNA of above three pure cultures, microbial consortium and soil sample from inoculated field was isolated for PCR and SSCP gel electrophoresis. Genomic DNA extraction and PCR analysis were carried out in the Department of Agricultural Microbiology, Tamil Nadu Agricultural University, Coimbatore. SSCP gel electrophoresis was carried out at the Department of Biology, Centre for Excellence in Genomic Science, Madurai Kamaraj University using the universal D Code $^{\mathrm{TM}}$ mutation detection system (BIO RAD) (Sekiya, 1996).

\section{Genomic DNA extraction}

Genomic DNA was extracted (Melody, 1997) from axenic cultures, liquid microbial consortium and soil samples collected from the microbial consortium inoculated field. To isolate genomic DNA, the Azospirillum, Bacillus and Pseudomonas cultures were grown in sodium malate broth (Okon et al., 1977), Luria - Bertani (Bertani, 1951) broth and King's B (King et al., 1954) broth respectively to get log phase growth within $12 \mathrm{hrs}$. One $\mathrm{mL}$ of the microbial consortium was inoculated into the LB broth, which was used for genomic DNA extraction. Soil samples were collected from the field after inoculation through biofertigation for isolation of specific microbes and genomic DNA extraction.

\section{Optimization of DNA mixing ratio for better PCR amplification}

To analyse DNA homology of three pure cultures strains with microbial consortium (mixed cultures) and inoculum from the field mixture, the genomic DNA of Azospirillum brasilense sp 7, Bacillus megaterium var. phosphaticum and Pseudomonas fluorescens were mixed @ 1.5, 2 and 3 ratios separately for check PCR analysis and the best ratio was selected for further works. The ratios were selected based on its DNA concentration and equalization.

\section{PCR amplification of 16s rRNA gene}

The 16S rRNA gene is highly conserved across domains of Bacteria and Archaea, and taxonomical assignment is possible due to the presence of nine hyper variable regions $\left(\mathrm{V}_{1}-\mathrm{V}_{9}\right)$ that 
contain sufficient sequence diversity to classify microbes. Moreover, since these variable regions are flanked by conserved regions, PCR amplification using universal primers is possible to find the specific region of each organism.

The primers were used to generate PCR fragment between 335 to 355 base pair such as forward 27F (5' G AGTT TGATCMTGGCTCAG 3') and reverse primer $355 \mathrm{R}$ (5' GCTGCCTCCCGTAGGAGT 3') for targeting $\mathrm{V}_{1}+\mathrm{V}_{2}$ region of 16srRNA gene. The amplicon targeting the $\mathrm{V}_{1}+\mathrm{V}_{2}$ region demonstrated the highest discrimination within three cultures $(95 \%)$ and helps to differentiate at species level.

\section{PCR reaction mixture and steps}

PCR reaction mixture $(30 \mu \mathrm{L})$ consists of Tag buffer (10x): $3.0 \mu \mathrm{L}$ dNTP mixture $(100 \mathrm{mM}$ $3.0 \mu \mathrm{L}), \mathrm{MgCl}_{2}(1.5 \mu \mathrm{L})$ forward primer $(50 \mathrm{ng}: 1.5 \mu \mathrm{L})$ and reverse primer $(50 \mathrm{ng}: 1.5 \mu \mathrm{L})$, Taq DNA polymerase (100 ng : $0.75 \mu \mathrm{L})$ Total DNA $(50 \mathrm{ng}: 1 \mu \mathrm{L})$ and sterile distilled water $(17.6 \mu \mathrm{L})$ were taken for amplification of the 16srRNA gene fragment. Reaction mixtures were given a momentary spin in a Biofuge for thorough mixing of the cocktail components. The PCR tubes were then loaded in a thermal cycler (Eppendorff, Germany) for amplification. PCR Steps were as follows viz., initial denaturation : $95{ }^{\circ} \mathrm{C}(5 \mathrm{~min})$, denaturation : $55^{\circ} \mathrm{C}(1 \mathrm{~min})$, Annealing: $72{ }^{\circ} \mathrm{C}(1 \mathrm{~min})$, Extension: $72{ }^{\circ} \mathrm{C}$ $(1 \mathrm{~min})$, and final extension $72{ }^{\circ} \mathrm{C}(1 \mathrm{~min})$ which covers 35 cycles for completion of all PCR steps.

\section{Gel electrophoresis and documentation}

Agarose gel electrophoresis was performed based on the method given by Sambrook et al. (1989) to check the quality of DNA ( $0.8 \%$ agarose) and also to separate the amplified product through polymerase chain reaction (1.5\% agarose). Gels were viewed and photographed using Alpha imager TM 1200 documentation and analysis system.

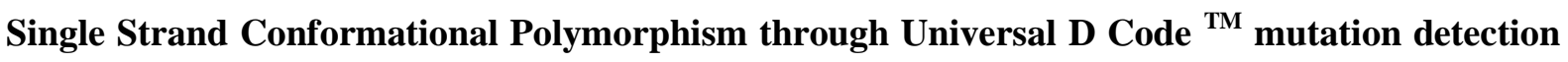 system}

Variable regions $\mathrm{V}_{1}-\mathrm{V}_{2}$ of the 16S rRNA gene were amplified using universal primer (as indicated above) from axenic culture of Azospirillum brasilense sp 7, Bacillus megaterium var. phosphaticum and Pseudomonas fluorescens $(P f$ 1), mixed DNA of three cultures, microbial consortium and genomic DNA isolated from the inoculated field. The PCR samples were loaded in polyacrylamide gel (D code mutation gel electrophoresis unit) after denaturation with $95^{\circ} \mathrm{C}$ for $5 \mathrm{~min}$ for single strand confirmation. SSCP gel electrophoresis was carried out under $4^{\circ} \mathrm{C}$ to prevent renaturation. After gel electrophoresis the gel was carefully removed for silver staining. Because the banding pattern of polyacrylamide gel will be visible only through silver staining in this case.

\section{Silver staining}

Silver staining consists of four steps (viz, fixation, washing, staining, rinsing, image development and stopping) were done. (Switzer et al., 1979, Wray, 1981 and Gottlieb \& Chavco, 1987).

\section{Result}

Compatability experiment revealed no competition or antibiosis between Azospirillum, Bacillus and Pseudomonas. Standardization of mixing ratio of inoculums experiment showed 2:1:0.5 is optimum for mixing of Azospirillum brasilense sp 7, Bacillus megaterium var. phosphaticum and Pseudomonas fluorescens to get $10^{12}$ cells $/ \mathrm{mL}$. The result of optimization of incubation time showed 20 days for Azospirillum brasilense sp 7, seven for Bacillus megaterium var. phosphaticum and 4 days for Pseudomonas fluorescens. It indicates Pseudomonas has very fast growth followed by phosphobacteria and Azospirillum has tripled the time slow growth than the other two strains. Liquid microbial consortium was inoculated in bhendi (COBH 1) field through biofertigation under precision farming system. The soil sample from inoculated field was taken for SSCP gel electrophoresis. 
The optimization of genomic DNA mixing ratio result showed 2:2:2 is the best one for three above mentioned pure culture for better PCR amplification (Figure 1). The PCR results of three pure cultures, mixed inoculants DNA, microbial consortium and soil sample from inoculated field resulted appearance of band between 300 to $400 \mathrm{bp}$ and no polymorphic difference were observed between the cultures due to double stranded DNA (Fig. 2).

The results of SSCP gel electrophoresis showed marker in first lane, followed by the PCR products of Azospirillum ( $2^{\text {nd }}$ lane $)$, Bacillus ( $3^{\text {rd }}$ lane $)$, Pseudomonas $\left(\left(4^{\text {th }}\right.\right.$ lane $)$, PCR product after mixing the DNA ( $5^{\text {th }}$ lane $)$ of three cultures, mixed product of three cultures after PCR $\left(6^{\text {th }}\right.$ lane $)$, PCR product of microbial consortium ( $7^{\text {th }}$ lane) and PCR product of inoculum collected from the field soil sample after biofertigation $\left(8^{\text {th }}\right.$ lane) respectively (Figure 3 ).

In gel picture (Fig. 3) Azospirillum brasiense sp7, one band was observed nearer to 355 base pair level. In case of Bacillus magaterium var. phosphaticum and Pseudomonas fluorescens one band was observed between 335 and 340 base pair level. The presence of $\mathrm{V}_{1}+\mathrm{V}_{2}$ domain of 16S rRNA of Azospirillum brasiense sp7 had showed polymorphic difference with both Bacillus megaterium var. phosphaticum and Pseudomonas fluorescens by comparison in $2^{\text {nd }}, 3^{\text {rd }}$ and $4^{\text {th }}$ lane. However, no polymorphic difference was observed between Bacillus megaterium var. phosphaticum and Pseudomonas fluorescens by comparison with $3^{\text {rd }}$ and $4^{\text {th }}$ lane. Since, the bands are in same place for Bacillus and Pseudomonas. The results suggested Azospirillum brasilese sp7 had 15 to 20 base pair level difference compared with both Bacillus megaterium var. phosphaticum and Pseudomonas fluorescens with regard to $\mathrm{V}_{1}+\mathrm{V}_{2}$ domain. This indicates the genetic homology between the Bacillus and Pseudomonas for $\mathrm{V}_{1}+\mathrm{V}_{2}$ region present in the $16 \mathrm{~S}$ rRNA.

In the case of mixed cultures containing sources viz., PCR product of microbial consortium inoculated in the field, microbial consortium, PCR product after mixing the DNA of three cultures and mixed PCR product of three cultures contains two bands such as one indicating the amplified $\mathrm{V}_{1}+\mathrm{V}_{2}$ domain of Azospirillum (355 bp) and the other band just above this band indicates the amplified domain $\left(\mathrm{V}_{1}+\mathrm{V}_{2}\right)$ of Bacillus and Pseudomonas (335 bp). The presence of inoculated microbial consortium in the field was confirmed by comparing the banding pattern of mixed cultures (lane $5^{\text {th }}$ and $6^{\text {th }}$ ), microbial consortium (lane $7^{\text {th }}$ ) and axenic cultures. The results confirmed the presence of inoculants strains of the microbial consortium in field by banding pattern of mixed cultures, microbial consortium together with pure cultures.

\section{Discussion}

Use of liquid microbial consortium for precision farming system is important agricultural practise followed nowadays. Microbial source of inoculants is important for organic agriculture and maintaining sustainability of soil fertility, health and soil microorganism. This experiment is focused to identify specific microorganism from field microbial community. This SSCP -PCR experiment revealed small variation within same length DNA of different organism can be identified without characterization. This technique can used to differentiate small variation between the same lengths DNA of different organism.

The PCR results of the Azospirillum, Bacillus and Pseudomonas produced similar size of band 350bp (Fig. 2) but it was not in the case of SSCP gel (335, $350 \mathrm{bp).} \mathrm{SSCP} \mathrm{gel} \mathrm{electrophoresis}$ result revealed the resolution of $\mathrm{V}_{1}+\mathrm{V}_{2}$ domain (330 to 350bp) of 16S rRNA of Azospirillum, Phosphobacteria and Pseudomonas. This result was supported by the finding Sheffield et al. (1993) who has reported SSCP is a simple and effective method for detection of minor sequence changes in DNA amplified by PCR. Orita et al., (1989) who suggested that higher resolution can be achieved when the PCR products of the 16S -23S rRNA intergenic spacer region are analyzed by single strand conformational polymorphism.

In the SSCP gel, Azospirillum produced 335bp and it was different from other two strains Bacillus and Pseudomonas which produced 350 bp. It expresses the sequencing difference of Azospirillum compared with Bacillus and Pseudomonas with regards to $\mathrm{V}_{1}+\mathrm{V}_{2}$ domain of $16 \mathrm{~S}$ rRNA. Bacillus and Pseudomonas strains produced $350 \mathrm{bp}$ size band which denotes the same size DNA of $\mathrm{V}_{1}+\mathrm{V}_{2}$ domain of 16S rRNA. This concluded the role of SSCP and its application on ss DNA of 
different strains. Beyond this some of the unknown bands were observed in the top portion of gel and these are the bands of reannealing of ss DNA caused while denaturation step. This was supported by the Selvakumar et al., (1997) who has reported high rate of reanealing of DNA strands after initial denaturation during electrophoresis. The confusion can be avoided by repeating experiment for getting same results of both single strands and double strand DNA. Eventhough the result need further confirmation through sequencing.

\section{Conclusion}

The result concluded SSCP -PCR can be used to differentiate the microorganism at genetic level with high resolution. It can be useful for phylogenetic classification and field level identification of microbes without characterization.

Acknowledgments
I would like to thank Dr. P. Gunasegaran, Senior Professor of Microbiology in India,
Chairperson, School of Biological Sciences, Former Professor and Head, Centre for Excellence in
Genomic Sciences, Madurai Kamaraj University and him student T. Rajesh for the assistantship and
guidance to work in that laboratory.

\section{References}

Allen, D.N. 1953. Experiments in Soil bacteriology (II ed.) Burgees Publ. Co., Indian J. Microbiol., 32: $469-472$.

Bertani, G. 1951. Studies on the lysogenesis. I. The mode of phage liberation Escherichi coli. J. Bacteriol., 62: 290-300.

Cocolin, L., L. F. Bisson and D. A. Mills. 2000. Direct profiling of the yeast dynamics in wine fermentations. FEMS Microbiol. Lett., 189: 81-87.

Coppola, S., G. Blaiotta, D. Ercolini, and G. Moschetti. 2001. Molecular evaluation of microbial diversity occurring in different types of mozzarella cheese. J. Appl. Microbiol., 90 : 414-420.

Diez, B., C. Pedros-Alio, T. L. Marsh and R. Massana. 2001. Application of denaturing gradient gel electrophoresis (DGGE) to study the diversity of marine picoeukaryotic assemblages and comparison of DGGE with other molecular techniques. Appl. Environ. Microbiol., 67 : 29422951.

Duthoit, F., J.J. Godenn and M.C. Montell. 2003. Bacterial community dynamics during production of registered designation of origin salers cheese as evaluated by 16srRNA gene single strand conformational polymorphism analysis. App. Environ. Microbiol., 69 (7) : 3840 - 8.

Felske, A, 1999. Reviewing the DA001-files: a 16S rRNA chase on suspect \#X99967, a Bacillus and Dutch underground activist. J. Microbiol. Methods, 36 : 77-93.

Felske, A., B. Engelen, U. Nubel, and H. Backhaus. 1996. Direct ribosome isolation from soil to extract bacterial rRNA for community analysis. Appl. Environ. Microbiol., 62:4162-4167.

Gottlieb, M. and K. Chavco. 1987. Anal. Biochem., 165: 33

King, K.O., M. K. Ward and D.E. Raney. 1954. Two simple media for the demonstration of pyocyanin and fluorescein. J. Lab. Clin. Med., 44: 301-307.

Leclerc, M., C. Delbes, R. Moletta, and J. J. Godon. 2001. Single strand conformation polymorphism monitoring of 16S rDNA Archaea during start-up of an anaerobic digester. FEMS Microbiol. Ecol., 34 : 213-220.

Lee, D. H., Y. G. Zo and S. J. Kim. 1996. Nonradioactive method to study genetic profiles of natural bacterial communities by PCR-single-strand-conformation polymorphism. Appl. Environ. Microbiol., 62:3112-3120.

Mahaffee, W. F. and J. W. Kloepper. 1997. Temporal changes in the bacterial communities of soil, rhizosphere, and endorhiza associated with field grown cucumber (Cucumis sativus L.). Microb. Ecol., 34 : 201-223.

Masato Orita, Hiroyuki Iwahana, Hiroshi Knazawa, Kenshi Hayashi and Takato Sekiya Detection of the polymorphisms of human DNA by gelelectrophoresis as single-strand conformation polymorphisms. Proc. Natd.Acad. Sci,. USA 86, 2766-2770, 1989. 
Melody, S. C. 1997. Plant Molecular biology. A laboratory manual. Springer-Verley, New York.

Mills, A. L. and R. A. Wassel. 1980. Aspects of diversity measurement for microbial communities. Appl. Environ. Microbiol., 40:578-586.

Moeseneder, M. M., J. M. Arrieta, G. Muyzer, C. Winter and G. J. Herndl. 1999. Optimization of terminal-restriction fragment length polymorphism analysis for complex marine bacterioplankton communities and comparison with denaturing gradient gel electrophoresis. Appl. Environ. Microbiol., 65: 3518-3525.

Ogier, J. C., O. Son, A. Gruss, P. Tailliez, and A. Delacroix-Buchet. 2002. Identification of the bacterial microflora in dairy products by temporal temperature gradient gel electrophoresis. Appl. Environ. Microbiol., 68 : 3691- 3701.

Okon, Y., S.L. Albrect and R.H. Burris. 1977. Carbon and ammonia metabolism of Spirillum lipoferum. J. Bacteriol., 128: 592 -597.

Orita, M., Y. Suzuki, T. Sekiya and K. Hayashi. 1989. Rapid and sensitive detection of point mutations and DNA polymorphisms using the polymerase chain reaction. Genomics, 5: $874-879$.

Osborn, A. M., E. R. B. Moore and K. N. Timmis. 2000. An evaluation of terminal-restriction fragment length polymorphism (T-RFLP) analysis for the study of microbial community structure and dynamics. Environ. Microbiol., 2:39-50.

Rangaswami, G. and D.J. Bagyaraj. 1993. Agricultural Microbiology, Prentice Hall of India Pvt. Ltd., New Delhi.

Sambrook, J., E.F. Fritsch and T. Maniatis. 1989. Molecular cloning. A laboratory manual $2^{\text {nd }}$ edition. Coid spring Harbor press, New York.

Scheinert, P., R. Kruse, U. Ullmann, R. Soller, and G. Krupp. 1996. Molecular differentiation of bacteria by PCR amplification of the 16S-23S rRNA spacer. J. Microbiol. Methods, 26:103117.

Sekiya, T. 1996. Technologies for detection of DNA damage and Mutation, chapter 21. Plenum Press, New York. $281-290$.

Selvakumar, N., B.-C. Ding and S. M. Wilson. 1997. Separation of DNA strands facilitates detection of point mutations by PCR-SSCP. Biotechniques, 22: 604-606.

Sheffield,V.C., J.S. Beck and A.E. Kwiteck. 1993. The sensitivity of single strand conformational polymorphism analysis for the detection of single base substitutions. Genomics, 16: 325-332.

Somasegaran, P. H., J. Hoben and V. Gurgun. 1988. Effects of inoculation rate, Rhizobium strain competition and nitrogen fixation in chickpea. Agron. J., 80: $68-73$.

Sperber, J.E. 1958. Solubilization of apatite by soil microorganisms producing organic acids. Aust. J. Agric. Res., 9: 782 -787.

Switzer, R.C., C.R. Merril and S. Shifrin. 1979. Anal. Biochem., $98: 231$

Turenne, C. Y., E. Witwicki, D. J. Hoban, J. A. Karlowsky and A. M. Kabani. 2000. Rapid identification of bacteria from positive blood cultures by fluorescence- based PCR-singlestrand conformation polymorphism analysis of the 16S rRNA gene. J. Clin. Microbiol., 38:513-520.

Wagner, M., R. Amann, H. Lemmer, and K.-H. Schleiffer. 1993. Probing activated sludge with oligonucleotides specific for proteobacteria: inadequacy of culture-dependent methods for describing microbial community structure. Appl. Environ. Microbiol., 59:1520-1525.

Ward, D. M., R. Weller, and M. M. Bateson. 1990. 16S rRNA sequences reveal numerous uncultured microorganisms in a natural community. Nature (London) $345: 63-65$.

Wray, W., T. Boulikas, V.P. Wray and R. Hancock. 1981. Anal. Biochem., 118 : 197.

Zoetendal, E. G., A. D. Akkermans and W. M. De Vos. 1998. Temperature gradient gel electrophoresis analysis of 16S rRNA from human fecal samples reveals stable and hostspecific communities of active bacteria. Appl. Environ. Microbiol., 64 : 3854-3859.

Zumstein, E., R. Moletta, and J. J. Godon. 2000. Examination of two years of community dynamics in an anaerobic bioreactor using fluorescence polymerase chain reaction (PCR) single-strand conformation polymorphism analysis. Environ. Microbiol., 2:69-78. 


\section{(Tables \& Figures)}

Fig 1. Optimization of DNA mixing ratio of three axenic cultures to fix good PCR amplification

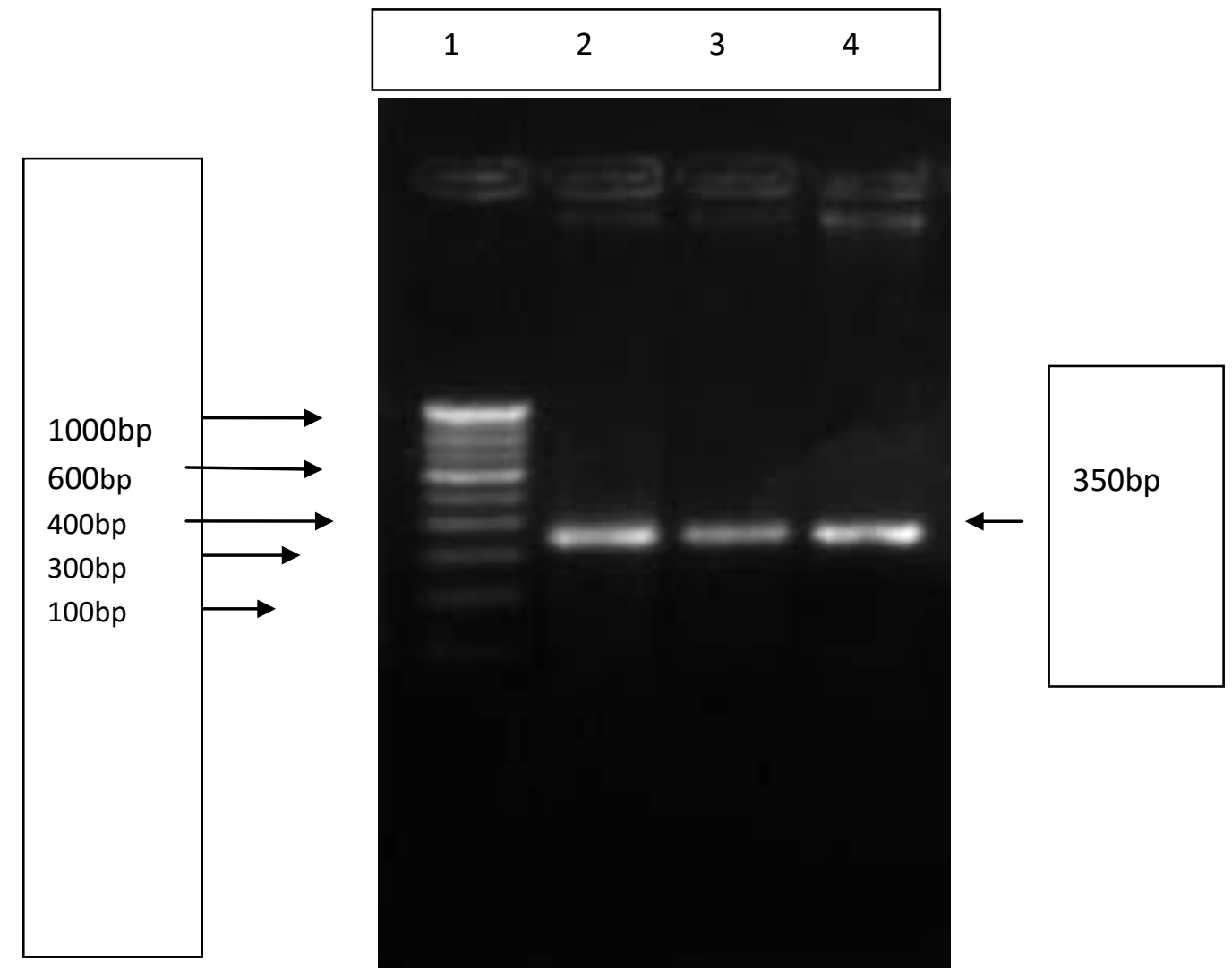

1. 100bp ladder

2. $\quad$ Mixed DNA (1.5:1.5:1.5) of axenic cultures

3. Mixed DNA (2:2:2) of axenic cultures

4. $\quad$ Mixed DNA (3:3:3) of axenic cultures

Culture 1. Azospirillum brasilense sp7

Culture 2. Bacillus megaterium var. phosphaticum

Culture 3. Pseudomonas fluorescens 
Fig 2. PCR amplification of the $\mathrm{V}_{1}+\mathrm{V}_{2}$ domain of 16srRNA region of the axenic cultures of the inoculant strains, microbial consortium and microbial consortium inoculated in the field through biofertigation

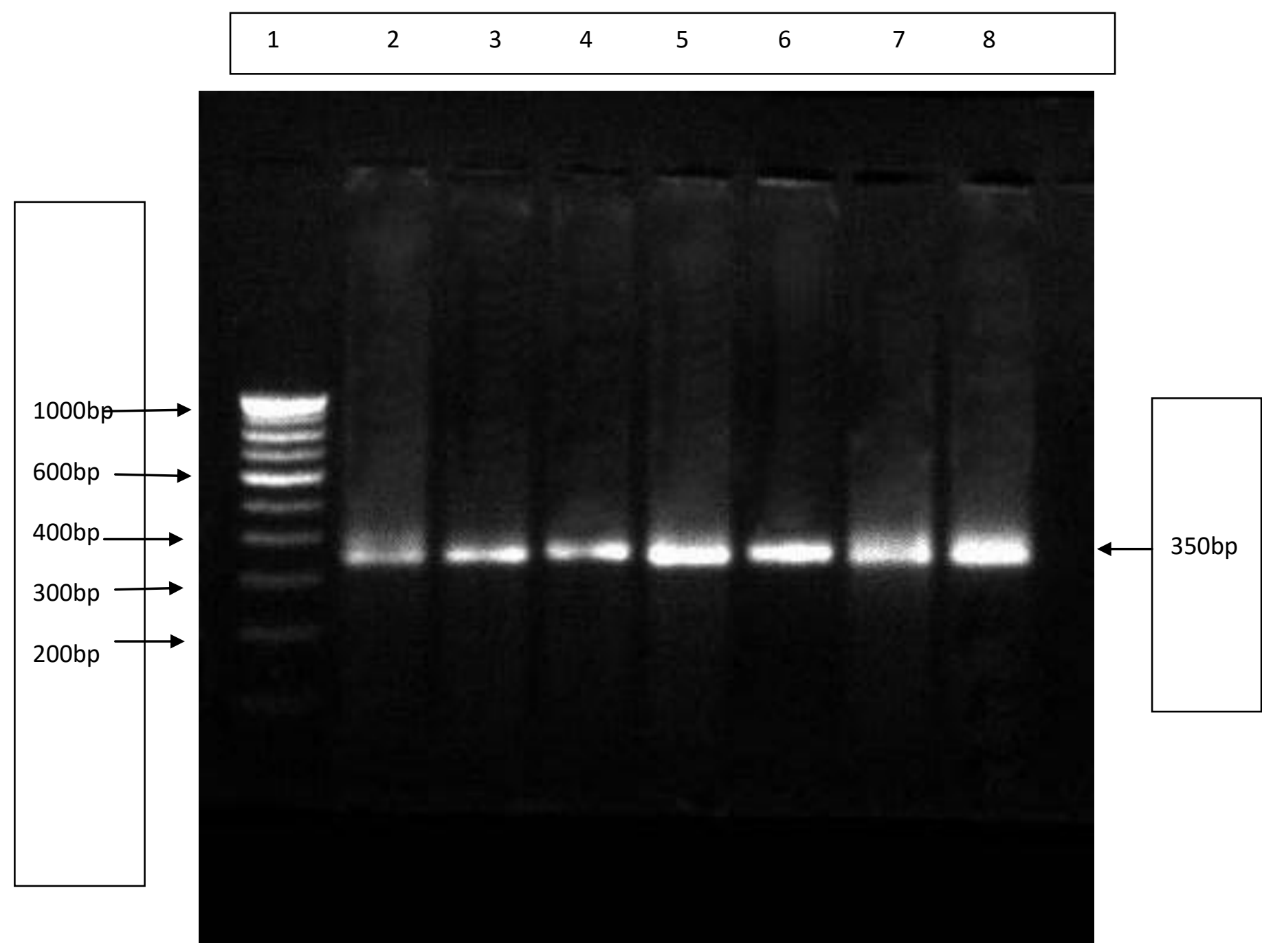

\begin{tabular}{|l|l|}
\hline 1. & 100bp ladder \\
\hline 2. & Azospirillum brasilense sp7 \\
\hline 3. & Bacillus megaterium var. phosphaticum \\
\hline 4. & Pseudomonas fluorescens \\
\hline 5 & PCR product after mixing DNA of 3 cultures \\
\hline 6 & Microbial consortium \\
\hline 7 & Microbial consortium inoculated in the field through biofertigation \\
\hline
\end{tabular}


Fig 3. Molecular detection of Azospirillum, Bacillus and Pseudomonas of the microbial consortium inoculated in the field in comparison with microbial consortium and axenic inoculant cultures by PCR amplification of $\mathrm{V}_{1}+\mathrm{V}_{2}$ domain of 16SrRNA and SSCP gel electrophoresis

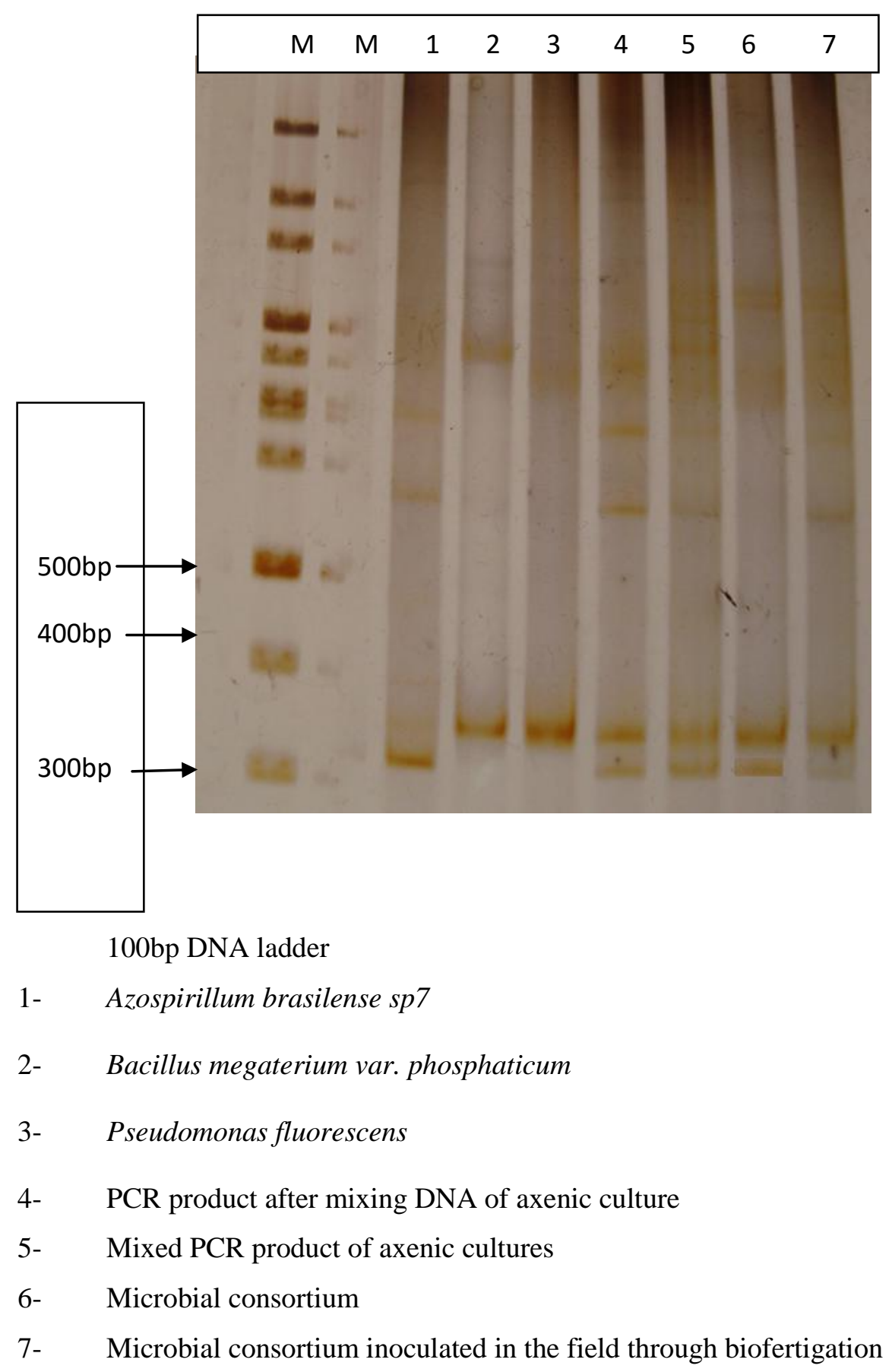

